\title{
Endostatin inhibits VEGF-A induced osteoclastic bone resorption in
} vitro

\author{
Annina Sipola1 ${ }^{1}$, Katri Nelo ${ }^{1}$, Timo Hautala ${ }^{2}$, Joanna Ilvesaro $^{1}$ and \\ Juha Tuukkanen*1
}

\begin{abstract}
Address: ${ }^{1}$ Dept. of Anatomy and Cell Biology, PO Box 5000, FIN-90014 University of Oulu, Finland and 2Department of Internal Medicine, PO Box 5000, FIN-90014 University of Oulu, Finland

Email: Annina Sipola - annina.sipola@oulu.fi; Katri Nelo - katri.nelo@oulu.fi; Timo Hautala - timo.hautala@oulu.fi; Joanna Ilvesaro - joanna.ilvesaro@ccc.uab.edu; Juha Tuukkanen* - juha.tuukkanen@oulu.fi

* Corresponding author
\end{abstract}

Published: 13 July 2006

BMC Musculoskeletal Disorders 2006, 7:56 doi:10.1 186/147/-2474-7-56

This article is available from: http://www.biomedcentral.com/I47/-2474/7/56

(c) 2006 Sipola et al; licensee BioMed Central Ltd.

This is an Open Access article distributed under the terms of the Creative Commons Attribution License (http://creativecommons.org/licenses/by/2.0), which permits unrestricted use, distribution, and reproduction in any medium, provided the original work is properly cited.
Received: 29 August 2005

Accepted: 13 July 2006

\begin{abstract}
Background: Endostatin is a C-terminal fragment of collagen XVIII which is a component of basement membranes with the structural properties of both collagens and proteoglycans. Endostatin has a major role in angiogenesis which is intimately associated with bone development and remodeling. Signaling between the endothelial cells and the bone cells, for example, may have a role in recruitment of osteoclastic precursor cells. Our study aims at exploring a possibility that endostatin, either as a part of basement membrane or as a soluble molecule, may control osteoclastogenesis and osteoclastic bone resorption in vitro.
\end{abstract}

Methods: Rat pit formation assay was employed in order to examine the effect of endostatin alone or in combination with vascular endothelial growth factor-A (VEGF-A) on bone resorption in vitro. Effect of these agents on osteoclast differentiation in vitro was also tested. Osteoclastogenesis and the number of osteoclasts were followed by tartrate resistant acid phosphatase (TRACP) staining and resorption was evaluated by measuring the area of excavated pits.

Results: Endostatin inhibited the VEGF-A stimulated osteoclastic bone resorption, whereas endostatin alone had no effect on the basal resorption level in the absence of VEGF-A. In addition, endostatin could inhibit osteoclast differentiation in vitro independent of VEGF-A.

Conclusion: Our in vitro data indicate that collagen XVIII/endostatin can suppress VEGF-A induced osteoclastic bone resorption to the basal level. Osteoclastogenesis is also inhibited by endostatin. The regulatory effect of endostatin, however, is not critical since endostatin alone does not modify the basal bone resorption.

\section{Background}

The development and continuous remodeling of the skeleton demand a tightly regulated balance between the bone-forming and bone-resorbing processes. One of the key components of bone remodeling is constant develop- ment of vasculature. Vasculature is required for transport of nutrients and precursor cells, such as precursors of chondroclasts and osteoclasts, to the renewing bone tissue. Angiogenesis has also been shown to be crucial for the replacement of cartilage by bone during skeletal 
growth and regeneration. Vascular endothelial growth factor-A (VEGF-A), produced by hypertrophic chondrocytes during endochondral bone formation, stimulates controlled invasion of chondroclasts into the cartilage $[1,2]$. VEGF-A is also a chemoattractant for endothelial cells and regulates the growth plate vascularisation of metaphyseal bone.

Invasion of osteoclasts into hypertrophic cartilage requires presence of VEGF-A [3] which binds with high affinity to two tyrosine kinase receptors, Flt- 1 and Flk-1 [4]. VEGF-A may attract osteoclast precursor cells that are recruited from hematopoietic tissue. It has been reported that VEGF-A is potentially a monocyte chemoattractant [5]. Monocytes express Flt-1, but not Flk-1 [6]. In response to VEGF-A, macrophages derived from Flt-1 mutant mice indicated deranged chemotaxis [7] demonstrating that Flt-1 may mediate the migration of monocyte/macrophage lineages. Mature osteoclasts have been shown to express Flt- 1 and Flk- 1 on their cells surface $[1,8-12]$ and both of these receptors may mediate the VEGF-A effect on bone formation and bone resorption [8]. Recently published data clearly indicates that VEGF-A is important both in endochondral and intramembranous ossification $[13,14]$. Precise mechanisms of the recruitment of osteoclast precursors into the site of bone resorption, however, remain unclear.

Endostatin, a known antagonist for VEGF-A, is $20 \mathrm{kDa}$ Cterminal fragment of collagen XVIII found in basal membranes. Endostatin, that binds to $\alpha \mathrm{v}$ - and $\alpha 5$-integrins [15], inhibits endothelial cell proliferation and it may inhibit angiogenesis and tumor growth [16]. Resorbing osteoclasts have been shown to express at least $\alpha \mathrm{v}$ integrins [17-19], creating a potential for endostatin to control osteoclast function. Role of endostatin on bone resorption or osteoclast differentiation, however, is not established.

Aim of our study was to further define possible role of endostatin and VEGF-A on osteoclasts in vitro. In order to investigate the direct effects of these angiogenic and antiangiogenic substances on osteoclast mediated bone resorption, we used classical resorption pit assay and osteoclast differentiation assay of bone marrow hematopoietic stem cells. We were, for the first time, able to demonstrate that endostatin has a significant regulatory role on both osteoclastic bone resorption and osteoclastogenesis in vitro.

\section{Methods}

\section{Osteoclast isolation and culture}

The procedure for the isolation and culture of osteoclasts described earlier by Boyde et al. and by Chambers et al. $[20,21]$ was modified slightly and has been described in detail previously [22]. Briefly, mechanically harvested osteoclasts from the long bones of 1- or 2-day-old Sprague-Dawley rat pups were allowed to attach to ultrasonicated bovine cortical bone slices $\left(0.125 \mathrm{~cm}^{2}\right.$ or 0.5 $\mathrm{cm}^{2}$ ). After 30 minutes, the nonattached cells were rinsed away, and the remaining cells on the bone slices were cultured in Dulbecco's modified Eagle's medium ( $\alpha$-MEM) buffered with $20 \mathrm{mM}$ HEPES and containing $0.84 \mathrm{~g}$ of sodium bicarbonate/liter, $2 \mathrm{mM}$ L-glutamine, $100 \mathrm{IU}$ of penicillin/ml, $100 \mu \mathrm{g}$ of streptomycin $/ \mathrm{ml}$ and $7-10 \%$ heat-inactivated fetal calf serum (FCS), at $+37^{\circ} \mathrm{C}\left(5 \% \mathrm{CO}_{2}\right.$ and $95 \%$ air). The cells were divided into ten groups: the control group had $\alpha$-MEM-FCS as their culture medium with no added substances (later referred as control), the VEGF-A-treated cells had $100 \mathrm{ng} / \mathrm{ml}, 50 \mathrm{ng} / \mathrm{ml}$ or $10 \mathrm{ng} /$ $\mathrm{ml}$ VEGF-A in $\alpha$-MEM-FCS (later referred as VEGF). The endostatin groups had $0.02,0.2$ or $2 \mu \mathrm{g} / \mathrm{ml}$ endostatin in $\alpha$-MEM-FCS (later referred as ENDO) and the last groups had both VEGF-A and endostatin added into the complete culture media (later referred as VEGF+ENDO). The last groups had $100 \mathrm{ng} / \mathrm{ml}$ VEGF-A and $2 \mu \mathrm{g} / \mathrm{ml}$ endostatin, $50 \mathrm{ng} / \mathrm{ml} \mathrm{VEGF-A} \mathrm{and} 0,2 \mu \mathrm{g} / \mathrm{ml}$ endostatin or $10 \mathrm{ng} / \mathrm{ml}$ VEGF-A and $0,02 \mu \mathrm{g} / \mathrm{ml}$ endostatin. The cells were allowed to grow for $48 \mathrm{~h}$, after which the bone slices were fixed with freshly made refrigerated $3 \%$ paraformaldehyde (PFA) and $2 \%$ sucrose in phosphate-buffered saline (PBS) for 10 minutes at room temperature. The data shown in this manuscript is gathered from three independent experiments, each of which gave identical results.

\section{Osteoclast differentiation assay}

The procedure for osteoclast differentiation described earlier by Takahashi et al. [23] was slightly modified. Mouse (C57BL/6, 8-12 weeks) bone marrow cells were isolated from mouse long bones by using syringe. After incubation at $+37^{\circ} \mathrm{C}$ for 2 hours non-attached cells were collected from petri dish. Mouse bone marrow cells were seeded in 24-well plates containing sonicated cortical bovine bone slices $\left(0.125-0.5 \mathrm{~cm}^{2}\right)$ at a concentration of $1 \times 10^{6}$ cells/ well. Cells on the bone slices were cultured in four groups: control, VEGF $(100 \mathrm{ng} / \mathrm{ml})$ and ENDO $(2 \mu \mathrm{g} / \mathrm{ml})$ and VEGF + ENDO respectively. The control group was cultured in $\alpha$-MEM medium (Sigma, UK) with $10 \%$ heatinactivated fetal calf serum (FCS), 2 mM L-glutamin, 100 $\mathrm{IU} / \mathrm{ml}$ penicillin, $10 \mu \mathrm{g} / \mathrm{ml}$ streptomycin and $20 \mathrm{mM}$ Hepes which medium will be later referred to as $\alpha$-MEMFCS. Cells were cultured in $500 \mu \mathrm{l} \alpha$-MEM containing 30 ng/ml RANKL (Peprotech Ec., UK) and $10 \mathrm{ng} / \mathrm{ml} \mathrm{M-CSF}$ (R\&D Systems). Half of the medium was replaced every 3rd day. Cells were cultured at $+37^{\circ} \mathrm{C}(5 \%$ CO2, 95\% air) for 7 days, after which the cultures were stopped by fixing the cells with $3 \%$ paraformaldehyde (PFA)/ $2 \%$ sucrose in PBS. 
A

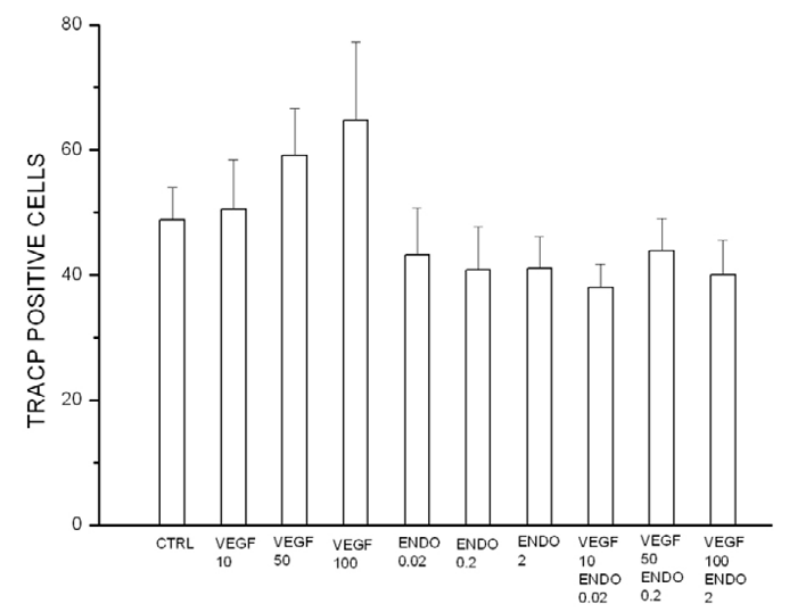

B

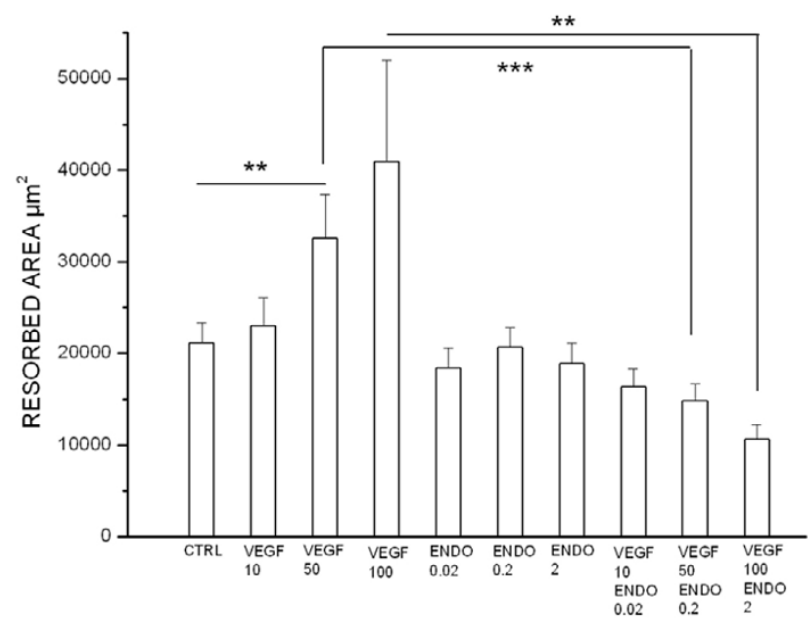

Figure I

Number of TRACP+ multinuclear cells and the activity of bone resorption in pit assay. Rat bone cells were cultured for 48 hours with no added substances (CONTROL), vascular endothelial growth factor $A$ (VEGF ng/ml), endostatin (ENDO $\mu \mathrm{g} / \mathrm{ml}$ ) or both VEGF-A and endostatin (VEGF $\mathrm{ng} / \mathrm{ml}$ +ENDO $\mu \mathrm{g} / \mathrm{ml}$ ). (A) Survival rate of osteoclasts after different treatments was measured by counting the numbers of TRACP-positive cells with two or more nuclei indicating osteoclasts. No significant differences in the number of osteoclasts could be seen. (B) Osteoclastic bone resorption could be visualized with WGA-lectin stain and total resorbed areas from the different cultures were measured. VEGF-A treatment induced a clear stimulus, whereas endostatin caused no effect on the resorbed area. Addition of both VEGF-A and endostatin caused a statistically significant decrease in the total resorbed area when compared to the VEGF-A-induced resorption. (VEGF $\mathrm{ng} / \mathrm{ml}$, ENDO $\mu \mathrm{g} /$ $\mathrm{ml})$

\section{TRACP staining}

Bone cells were cultured for 48 hours in resorption pit assay and 7 days in the differentiation assay. After the culture period, bone slices were fixed as described above. The cells were stained for tartrate-resistant acid phosphatase (TRACP), a commonly accepted marker of osteoclasts [24] using a Sigma TRACP kit (no. 386-A, Sigma Chemicals, St. Louis, MO) according to the manufacturer's instructions. To visualize the nuclei, the cells were incubated with the DNA-binding fluorochrome Hoechst $33258(1 \mathrm{mg} / \mathrm{ml}$ stock diluted 1:800 in PBS, Sigma Chemical Co, St. Louis, MO) for 10 minutes at room temperature. The numbers of multinucleated TRACP-positive cells on each bone slice were counted, using a Nikon Eclipse 600 microscope and Nikon Plan Fluor 20×/0.50 objective with an appropriate filterset.

\section{Area measurement of excavated pits}

Prior to the staining of the pits, total detachment of the cells from the bone slices was ensured by wiping the cellular surface of the slices with a soft brush. The pits were stained with peroxidase-conjugated wheat germ agglutinin-lectin (WGA; $20 \mu \mathrm{g} / \mathrm{ml}$, Sigma Chemical Co., St. Louis, MO) for 20 minutes, washed with PBS, and incubated for 5 minutes in diaminobenzidine $(0,5 \mathrm{mg} / \mathrm{ml})$ $+0,03 \% \mathrm{H}_{2} \mathrm{O}_{2}$. Morphometric analysis of the resorption pits was performed with an MCID image analyzer, utilizing $\mathrm{M}_{2}$ software (Imaging Research Inc., Brock University, Ontario, Canada).

\section{Statistical analysis}

Data presented are the results of at least two independent experiments. Values are the mean \pm SEM. Significance was calculated using one-way ANOVA followed by Student's ttest with statistical package Origin 6.0. The p-values less than 0.05 were considered as significant.

\section{Results}

\section{Bone resorption assay}

The number of osteoclasts after 48 hours in each sample group was counted by analyzing multinuclear TRACPpositive cells in the resorption assay. No significant differences in the number osteoclasts were found between the different groups (Fig 1A) indicating that none of the treatments was toxic to these cells.

The total resorbed area was significantly increased in response to VEGF-A treatment and the effect was dose dependent (Fig. 1B). Endostatin alone had no inhibitory effect on the resorbed area when compared to the basal level of osteoclastic bone resorption. When both endostatin and VEGF-A were supplemented, the stimulatory effect by VEGF-A on bone resorption was halted to the basal level. The resorption activity was even below basal level with the highest concentrations $(p<0.05$ in ctrl vs. 

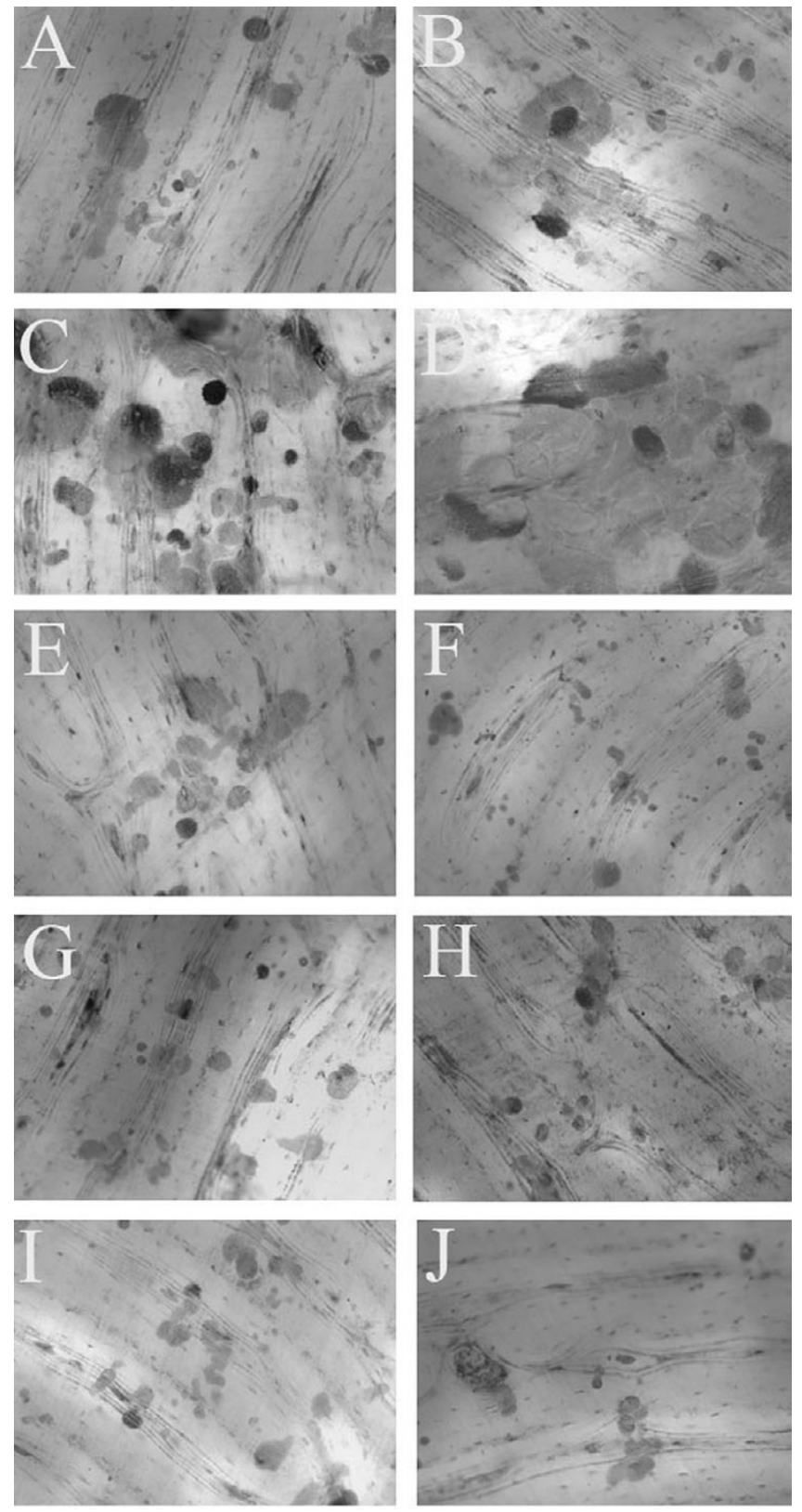

\section{Figure 2}

Typical appearance of the bone slices in the pit assay. Rat bone cells were cultured on bovine bone slices with different treatments. After 48 hours, cells were wiped off and resorbed bone area was visualized with image analyzer system. Bone slices after (A) Control (B) VEGF-A $10 \mathrm{ng} / \mathrm{ml}$ (C) VEGF-A $50 \mathrm{ng} / \mathrm{ml}$ (D) VEGF-A $100 \mathrm{ng} / \mathrm{ml}$ (E) Endostatin 0.02 $\mu \mathrm{g} / \mathrm{ml}$ (F) Endostatin $0.2 \mu \mathrm{g} / \mathrm{ml}$ (G) Endostatin $2 \mu \mathrm{g} / \mathrm{ml}$ (H) VEGF-A $10 \mathrm{ng} / \mathrm{ml}$ and Endostatin $0.02 \mu \mathrm{g} / \mathrm{ml}$ (I) VEGF-A 50 $\mathrm{ng} / \mathrm{ml}$ and Endostatin $0.2 \mu \mathrm{g} / \mathrm{ml}(J)$ VEGF-A $100 \mathrm{ng} / \mathrm{ml}$ and Endostatin $2 \mu \mathrm{g} / \mathrm{ml}$ treatments. Scale bar $100 \mu \mathrm{m}$.
VEGF100 and endostatin). Thus, endostatin could block the VEGF-A-induced stimulatory effect on osteoclastic bone resorption. These results are also demonstrated in figure 2 in which representative bone slices are shown.

\section{Osteoclast differentiation}

In the presence of RANKL and M-CSF the bone marrow hematopoietic cells differentiate into osteoclasts which can be recognized by positive TRACP-stain and multinuclear appearance. Since the basal resorption was not affected by endostatin in the pit assay, we conducted an assay to investigate if endostatin could inhibit the differentiation of osteoclasts. We added VEGF-A to the medium containing M-CSF and RANKL in order to achieve maximal differentiation stimulus (Fig. 3). Endostatin was able to abolish the maximal osteoclastogenesis and to reduce the number of TRACP+ cells in the presence of VEGF, RANKL and M-CSF or RANKL and M-CSF only.

\section{Discussion}

Bone remodeling is initiated by recruitment of osteoclast precursor cells from bone marrow or circulating monocytes. Homing of these precursors through the vascular wall is required for successful bone turnover. Intimate contact of the bone remodeling site to adjacent vascular sinusoids indicates interplay between the vascular endothelium and the bone cells. Co-culture of osteoblasts and endothelial cells stimulate the osteoblasts to secrete VEGF-A and to express RANKL, which is crucial for osteoclastogenesis [25]. VEGF-A is a chemoattractant for osteoclasts and lack of VEGF-A halts invasion of osteoclasts into hypertrophic cartilage through an MMP-9 dependent mechanism [3]. The similar kinetics and signaling pathways of RANKL and VEGF-A as chemoattractants differ from those of M-CSF [26]. The significance of VEGF-A in osteoclastogenesis is clearly demonstrated in osteopetrotic mice with a mutation in the M-CSF gene [27-29]. The mice have severe deficiency of osteoclasts, monocytes, and peritoneal macrophages. Injections of purified recombinant human M-CSF (rhM-CSF) compensate for these deficiencies in the mutant mice [30-33]. Interestingly, a single injection of rhVEGF-A can substitute M-CSF and cure osteopetrosis [8].

Significance of endostatin in bone has been demonstrated elegantly in the ex vivo metatarsal model in which fusion and migration of osteoclast precursors is required for the osteoclastic bone resorption [26]. Osteoclastic recruitment from periosteum can be inhibited by endostatin, leading to blocked dissolution of the calcified matrix in the developing marrow cavity. Endostatin completely inhibits VEGF-A and placental growth factor-2 mediated osteoclast invasion but has no effect on RANKL or M-CSF induced migration. The recruitment and invasion of osteoclast precursors can be disturbed by endostatin in the 


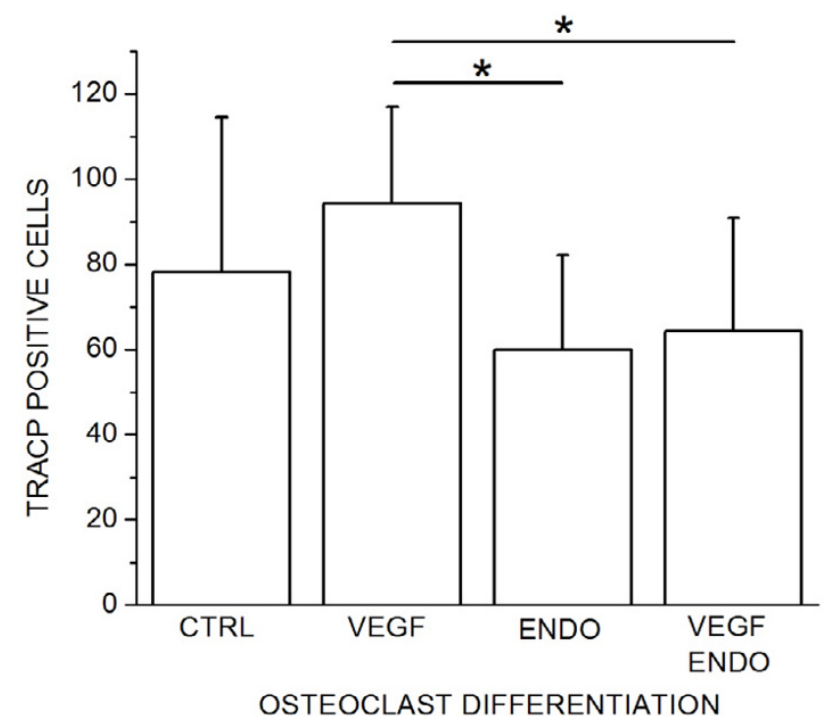

Figure 3

The number of TRACP+ multinuclear cells. Mouse (C57BL/6, 8-12 weeks) bone marrow cells were isolated from mouse long bones and seeded in 24-well plates on bovine bone slices. Cells on the bone slices were cultured in four groups: control, VEGF (I00 ng/ml) and ENDO $(2 \mu \mathrm{g} / \mathrm{ml})$ and VEGF + ENDO respectively. The control group was cultured in $\alpha-M E M$ with $10 \%$ FCS containing $30 \mathrm{ng} / \mathrm{ml}$ RANKL and $10 \mathrm{ng} / \mathrm{ml} \mathrm{M}-\mathrm{CSF}$ for 7 days, after which the cultures were stopped by fixing the cells with $3 \%$ paraformaldehyde (PFA)/ $2 \%$ sucrose in PBS.

metatarsal model. Correspondingly, soluble Flt-1 blocks invasion of osteoclasts into the marrow cavity of developing long bones in vivo [8]. In our pit formation assay in vitro, mature osteoclasts already exist. Still, we see a clear reduction of VEGF-A-stimulated resorption in the endostatin treated pit assays. Thus, it is possible that endostatin may not only limit the migration of osteoclast precursors, but it may also inhibit the VEGF-A-induced osteoclast activation. Pufe et al. have detected similar influence of endostatin on hyaline articular cartilage. Endostatin alone had no effect on basal levels on the phosphorylation of ERK1/2, whereas co-incubation with endostatin blocked VEGF-induced ERK1/2 phosphorylation in immortalized human chondrocytes (C28/I2) $[34,35]$.

Osteoclast precursor differentiation into mature osteoclasts is disturbed in the absence of VEGF-A [5]. VEGF-A also aids in the bone-resorbing function of osteoclasts $[8,11]$. Nakagawa and co-workers [11] have shown that the presence of VEGF-A enhances survival of pure rabbit osteoclasts and increases the resorbed bone area. In our resorption pit assay containing osteoblasts and osteo- clasts, however, the number of TRACP-positive cells remained unchanged (Fig. 1A). The data show that the increased total resorbed area in our model (Fig. 1B) is not due to enhanced survival rate. The observed effect is more likely a result of a direct VEGF-A stimulation on osteoclastic bone resorption.

Combination of RANKL, M-CSF, and VEGF-A activated intense differentiation of osteoclasts in our study in vitro. RANKL and VEGF-A stimulate the osteoclast recruitment through the same signaling pathway [26] and these pathways were most likely fully stimulated in our cell cultures. Endostatin, however, inhibited osteoclastogenesis when compared to this maximal stimulus (achieved with the combination of M-CSF, RANKL, and VEGF-A). Interestingly, the inhibitory effect was also seen in the absence of VEGF-A. This result indicates that inhibition by endostatin cannot be solely explained as an antagonism of VEGFA.

Endostatin did not inhibit basal bone resorption in our in vitro experiments suggesting that regulatory role of endostatin on osteoclasts may not be critical. In pathological conditions, however, endostatin may have a significant position. Endostatin is normally found in serum [36,37] and a possible therapeutic role for endostatin has been studied in cancer with promising results [38-40]. Endostatin could also be considered as a physiological inhibitor of inflammation induced neovascularization in arthritis patients. VEGF-A levels are elevated in arthritis and thus osteoclastic bone resorption is enhanced. Recently a clinical trial on patients with rheumatoid arthritis showed increased serum endostatin levels after a single injection of a TNF- $\alpha$ antibody. In addition, endostatin overexpression inhibited development of arthritis in the joints of TNF-transgenic mice [41]. Our in vitro data support the possibility that endostatin could be used as a physiological agent to inhibit the osteoclast activity in inflammatory arthritis. Further in vivo studies in animal models may be considered to explore that possibility.

\section{Conclusion}

Our in vitro data indicate that collagen XVIII/endostatin can suppress VEGF-A induced osteoclastic bone resorption to the basal level. Osteoclastogenesis is also inhibited by endostatin. The regulatory effect of endostatin, however, is not critical since endostatin alone does not modify the basal bone resorption.

\section{Competing interests}

The author(s) declare that they have no competing interests. 


\section{Authors' contributions}

AS, KN and JI have performed the cell cultures and their examination including the statistical analysis and together with TH and JT participated in development of the experiments. All authors have read and approved the final manuscript.

\section{Acknowledgements}

We thank Taina Poikela and Anna-Maija Ruonala for their skilful technical assistance. This work was supported by grants from the National Graduate School for Musculoskeletal Diseases in Finland and from the Finnish Dental Society Apollonia.

\section{References}

I. Gerber HP, Vu TH, Ryan AM, Kowalski J, Werb Z, Ferrara N: VEGF couples hypertrophic cartilage remodeling, ossification and angiogenesis during endochondral bone formation. Nat Med 1999, 5:623-628.

2. Olsen BR, Reginato AM, Wang W: Bone development. Annu Rev Cell Dev Biol 2000, 16:19|-220.

3. Engsig MT, Chen QJ, Vu TH, Pedersen AC, Therkidsen B, Lund LR, Henriksen K, Lenhard T, Foged NT, Werb Z, Delaisse JM: Matrix metalloproteinase 9 and vascular endothelial growth factor are essential for osteoclast recruitment into developing long bones. J Cell Biol 2000, I 5 I:879-889.

4. Millauer B, Wizigmann-Voos S, Schnurch H, Martinez R, Moller NP, Risau W, Ullrich A: High affinity VEGF binding and developmental expression suggest Flk-I as a major regulator of vasculogenesis and angiogenesis. Cell 1993, 72:835-846.

5. Clauss M, Weich H, Breier G, Knies U, Rockl W, Waltenberger J, Risau W: The vascular endothelial growth factor receptor FltI mediates biological activities. Implications for a functional role of placenta growth factor in monocyte activation and chemotaxis. J Biol Chem 1996, 27 I: I7629-17634.

6. Barleon B, Sozzani S, Zhou D, Weich HA, Mantovani A, Marme D: Migration of human monocytes in response to vascular endothelial growth factor (VEGF) is mediated via the VEGF receptor flt-I. Blood 1996, 87:3336-3343.

7. Hiratsuka S, Minowa O, Kuno J, Noda T, Shibuya M: FIt-I lacking the tyrosine kinase domain is sufficient for normal development and angiogenesis in mice. Proc Natl Acad Sci U S A 1998, 95:9349-9354.

8. Niida S, Kaku M, Amano H, Yoshida H, Kataoka H, Nishikawa S, Tanne K, Maeda N, Nishikawa S, Kodama H: Vascular endothelial growth factor can substitute for macrophage colony-stimulating factor in the support of osteoclastic bone resorption. J Exp Med 1999, 190:293-298.

9. Harada S, Nagy JA, Sullivan KA, Thomas KA, Endo N, Rodan GA, Rodan SB: Induction of vascular endothelial growth factor expression by prostaglandin E2 and EI in osteoblasts. J Clin Invest 1994, 93:2490-2496.

10. Harada S, Rodan SB, Rodan GA: Expression and regulation of vascular endothelial growth factor in osteoblasts. Clin Orthop Relat Res 1995:76-80.

II. Nakagawa M, Kaneda T, Arakawa T, Morita S, Sato T, Yomada T, Hanada K, Kumegawa M, Hakeda Y: Vascular endothelial growth factor (VEGF) directly enhances osteoclastic bone resorption and survival of mature osteoclasts. FEBS Lett 2000, 473:161-164.

12. Aoyama J, Tanaka E, Miyauchi M, Takata T, Hanaoka K, Hattori Y, Sasaki $A$, Watanabe $M$, Tanne $K$ : Immunolocalization of vascular endothelial growth factor in rat condylar cartilage during postnatal development. Histochem Cell Biol 2004, I 22:35-40.

13. Zelzer E, McLean W, Ng YS, Fukai N, Reginato AM, Lovejoy S, D'Amore PA, Olsen BR: Skeletal defects in VEGF(I 20// 20) mice reveal multiple roles for VEGF in skeletogenesis. Development 2002, I 29:1893-1904.

14. Tarkka T, Sipola A, Jamsa T, Soini Y, Yla-Herttuala S, Tuukkanen J, Hautala T: Adenoviral VEGF-A gene transfer induces angiogenesis and promotes bone formation in healing osseous tissues. J Gene Med 2003, 5:560-566.
15. Rehn M, Veikkola T, Kukk-Valdre E, Nakamura H, Ilmonen M, Lombardo C, Pihlajaniemi T, Alitalo K, Vuori K: Interaction of endostatin with integrins implicated in angiogenesis. Proc Natl Acad Sci U S A 200I, 98:1024-1029.

16. O'Reilly MS, Boehm T, Shing Y, Fukai N, Vasios G, Lane WS, Flynn E, Birkhead JR, Olsen BR, Folkman J: Endostatin: an endogenous inhibitor of angiogenesis and tumor growth. Cell 1997, 88:277-285.

17. Chuntharapai A, Bodary S, Horton M, Kim KJ: Blocking monoclonal antibodies to alpha $V$ beta 3 integrin: a unique epitope of alpha $\mathbf{V}$ beta 3 integrin is present on human osteoclasts. Exp Cell Res 1993, 205:345-352.

18. Davies J, Warwick J, Totty N, Philp R, Helfrich M, Horton M: The osteoclast functional antigen, implicated in the regulation of bone resorption, is biochemically related to the vitronectin receptor. J Cell Biol 1989, 109:1817-1826.

19. Duong LT, Lakkakorpi P, Nakamura I, Rodan GA: Integrins and signaling in osteoclast function. Matrix Biol 2000, 19:97-105.

20. Boyde A, Ali NN, Jones SJ: Resorption of dentine by isolated osteoclasts in vitro. Br Dent J 1984, I56:216-220.

21. Chambers TJ, Revell PA, Fuller K, Athanasou NA: Resorption of bone by isolated rabbit osteoclasts. J Cell Sci 1984, 66:383-399.

22. Lakkakorpi P, Tuukkanen J, Hentunen T, Jarvelin K, Vaananen K: Organization of osteoclast microfilaments during the attachment to bone surface in vitro. J Bone Miner Res 1989, 4:817-825.

23. Takahashi N, Yamana H, Yoshiki S, Roodman GD, Mundy GR, Jones SJ, Boyde A, Suda T: Osteoclast-like cell formation and its regulation by osteotropic hormones in mouse bone marrow cultures. Endocrinology 1988, I 22: 1373-1382.

24. Minkin C: Bone acid phosphatase: tartrate-resistant acid phosphatase as a marker of osteoclast function. Calcif Tissue Int 1982, 34:285-290.

25. Villars F, Bordenave L, Bareille R, Amedee J: Effect of human endothelial cells on human bone marrow stromal cell phenotype: role of VEGF? J Cell Biochem 2000, 79:672-685.

26. Henriksen K, Karsdal M, Delaisse JM, Engsig MT: RANKL and vascular endothelial growth factor (VEGF) induce osteoclast chemotaxis through an ERK I/2-dependent mechanism. J Biol Chem 2003, 278:48745-48753.

27. Marks SC], Lane PW: Osteopetrosis, a new recessive skeletal mutation on chromosome 12 of the mouse. J Hered 1976, 67:1I-18.

28. Marks SC): Morphological evidence of reduced bone resorption in osteopetrotic (op) mice. Am J Anat 1982, 163:157-167.

29. Wiktor-Jedrzejczak WW, Ahmed A, Szczylik C, Skelly RR: Hematological characterization of congenital osteopetrosis in op/op mouse. Possible mechanism for abnormal macrophage differentiation. J Exp Med 1982, 156:1516-1527.

30. Sundquist KT, Cecchini MG, Marks SC): Colony-stimulating factor-I injections improve but do not cure skeletal sclerosis in osteopetrotic (op) mice. Bone 1995, 16:39.

31. Kodama H, Nose M, Niida S, Yamasaki A: Essential role of macrophage colony-stimulating factor in the osteoclast differentiation supported by stromal cells. J Exp Med I99|, I73:I29|-1294.

32. Kodama H, Yamasaki A, Nose M, Niida S, Ohgame Y, Abe M, Kumegawa $M$, Suda T: Congenital osteoclast deficiency in osteopetrotic (op/op) mice is cured by injections of macrophage colony-stimulating factor. J Exp Med 1991, 173:269-272.

33. Felix R, Cecchini MG, Fleisch H: Macrophage colony stimulating factor restores in vivo bone resorption in the op/op osteopetrotic mouse. Endocrinology 1990, 127:2592-2594.

34. Pufe T, Mentlein R, Tsokos M, Steven P, Varoga D, Goldring MB, Tillmann BN, Paulsen FP: VEGF expression in adult permanent thyroid cartilage: implications for lack of cartilage ossification. Bone 2004, 35:543-552.

35. Pufe T, Petersen WJ, Miosge N, Goldring MB, Mentlein R, Varoga DJ, Tillmann BN: Endostatin/collagen XVIII--an inhibitor of angiogenesis--is expressed in cartilage and fibrocartilage. Matrix Biol 2004, 23:267-276.

36. Sasaki T, Fukai N, Mann K, Gohring W, Olsen BR, Timpl R: Structure, function and tissue forms of the C-terminal globular domain of collagen XVIII containing the angiogenesis inhibitor endostatin. EMBO J 1998, 17:4249-4256. 
37. Feldman AL, Pak H, Yang JC, Alexander HRJ, Libutti SK: Serum endostatin levels are elevated in patients with soft tissue sarcoma. Cancer 200I, 91:1525-1529.

38. Shi W, Teschendorf C, Muzyczka N, Siemann DW: Adeno-associated virus-mediated gene transfer of endostatin inhibits angiogenesis and tumor growth in vivo. Cancer Gene Ther 2002 9:5I3-52I.

39. Calvo A, Feldman AL, Libutti SK, Green JE: Adenovirus-mediated endostatin delivery results in inhibition of mammary gland tumor growth in C3(I)/SV40 T-antigen transgenic mice. Cancer Res 2002, 62:3934-3938.

40. Indraccolo S, Gola E, Rosato A, Minuzzo S, Habeler W, Tisato V, Roni V, Esposito G, Morini M, Albini A, Noonan DM, Ferrantini M, Amadori A, Chieco-Bianchi L: Differential effects of angiostatin, endostatin and interferon-alpha(I) gene transfer on in vivo growth of human breast cancer cells. Gene Ther 2002, 9:867-878.

4I. Kucharz EJ, Gozdzik J, Kopec M, Kotulska A, Lewicki M, Pieczyrak R, Widuchowska M, Zakliczynska H, Szarzynska-Ruda M, Zycinska-Debska $E$ : A single infusion of infliximab increases the serum endostatin level in patients with rheumatoid arthritis. Clin Exp Rheumatol 2003, $21: 273-274$.

\section{Pre-publication history}

The pre-publication history for this paper can be accessed here:

http://www.biomedcentral.com/1471-2474/7/56/prepub

Publish with Biomed Central and every scientist can read your work free of charge

"BioMed Central will be the most significant development for disseminating the results of biomedical research in our lifetime. "

Sir Paul Nurse, Cancer Research UK

Your research papers will be:

- available free of charge to the entire biomedical community

- peer reviewed and published immediately upon acceptance

- cited in PubMed and archived on PubMed Central

- yours - you keep the copyright 